\title{
PURIFICATION AND CHARACTERISATION OF AN EXTRACELLULAR PHYTASE FROM ASPERGILLUS NIGER 11T53A9
}

\author{
Ralf Greiner $^{1^{*}}$, Lucineia Gomes da Silva ${ }^{2,3}$, Sonia Couri ${ }^{2}$ \\ ${ }^{1}$ Department of Food and Bio Process Engineering, Max Rubner-Institute, Federal Research Institute of Nutrition and Food, Haid- \\ und-Neu-Straße 9, D-76131 Karlsruhe, Germany; ${ }^{2}$ CEFET, Química de Nilópolis, Maracanã, RJ, Brasil; ${ }^{3}$ Empresa Brasileira de \\ Pesquisa Agropecuária, Tecnologia de Alimentos, Guaratiba, RJ, Brasil.
}

Submitted: November 07, 2008; Returned to authors for corrections: February 10, 2009; Approved: June $28,2009$.

\begin{abstract}
An extracellular phytase from Aspergillus niger 11T53A9 was purified about 51-fold to apparent homogeneity with a recovery of $20.3 \%$ referred to the phytase activity in the crude extract. Purification was achieved by ammonium sulphate precipitation, ion chromataography and gel filtration. The purified enzyme behaved as a monomeric protein with a molecular mass of about $85 \mathrm{kDa}$ and exhibited maximal phytate-degrading activity at $\mathrm{pH}$ 5.0. Optimum temperature for the degradation of phytate was $55^{\circ} \mathrm{C}$. The kinetic parameters for the hydrolysis of sodium phytate were determined to be $\mathrm{K}_{\mathrm{M}}=54 \mu \mathrm{mol} \mathrm{l}^{-1}$ and $\mathrm{k}_{\mathrm{cat}}=190 \mathrm{sec}^{-1}$ at $\mathrm{pH} 5.0$ and $37^{\circ} \mathrm{C}$. The purified enzyme was rather specific for phytate dephosphorylation. It was shown that the phytase preferably dephosphorylates myo-inositol hexakisphosphate in a stereospecific way by sequential removal of phosphate groups via D-Ins $(1,2,4,5,6) \mathrm{P}_{5}$, D-Ins $(1,2,5,6) \mathrm{P}_{4}$, D-Ins(1,2,6) $\mathrm{P}_{3}$, D-Ins $(1,2) \mathrm{P}_{2}$ to finally Ins(2)P.
\end{abstract}

Key words: Aspergillus niger; phytate-degrading enzyme; phytate; phytase

\section{INTRODUCTION}

Much scientific information has been reported in the last few years linking diet, specific foods, or individual food components with the maintenance of human health and the prevention of chronic diseases such as coronary heart disease, cancer or osteoporosis. Individual myo-inositol phosphate esters have been shown to have important physiological functions in man (22). Some of these compounds, in particular D-Ins $(1,4,5) \mathrm{P}_{3}$ and $\mathrm{D}$-Ins $(1,3,4,5) \mathrm{P}_{4}$, have been demonstrated to play an important role as intracellular second messengers (22), and several isomers of myo-inositol phosphates have shown important pharmacological effects, such as prevention of diabetes complications and antiinflammatory effects $(2,5)$ as well as antiangiogenic and antitumour effects (17). In addition, dietary myo-inositol phosphates have been suggested to bring about benefits for human health, such as amelioration of heart disease conditions by controlling hypercholesterolemia and atheriosclerosis (14), prevention of renal stone formation (8), and protection against a variety of cancers, in particular colon cancer (31).

\footnotetext{
*Corresponding Author. Mailing address: Max Rubner-Institute, Federal Research Institute of for Nutrition and Food Department of Food and Bio Process Engineering Haid-und-Neu-Straße 9 - 76131 Karlsruhe (Germany).; Phone: +49 (0) 721 / 6625300 Fax: +49 (0) 721 / 6625 303.; E-mail:

ralf.greiner@mri.bund.de
} 
During food processing and digestion, phytate can be partially dephosphorylated by phytate-degrading enzymes (phytases) to yield a large number of positional isomers of myo-inositol pentakis-, tetrakis-, tris-, bis-, and monophosphates. The number and distribution of the phosphate residues on the myo-inositol ring determines the metabolic effects triggered by the individual myo-inositol phosphate isomer. Different phytases [myoinositol $(1,2,3,4,5,6)$ hexakisphosphate phosphohydrolases] may exhibit different phytate degradation pathways and therefore lead to the generation and accumulation of different myo-inositol phosphate intermediates. Phytate-degrading activity has been detected in plants, micro-organisms, and in some animal tissues $(15,30)$ and phytases from several plant and microbial species have been purified and characterised. Furthermore, the complete pathway of enzymatic phytate dephosphorylation was elucidated for several phytases. From these studies it was concluded that the phosphate residue at position C-2 of the myo-inositol is resistant to dephosphorylation by phytases (15). There was only one exception reported so far in the scientific literature. For the phytase of Aspergillus niger var. ficuum a dual phytate dephosphorylation pathway resulting in the generation of two myo-inositol trisphosphates was reported (4). The appearance of D-Ins $(1,5,6) \mathrm{P}_{3}$ as one of the myo-inositol trisphosphate intermediates requires removal of the phosphate residue at position 2 of the myo-inositol ring. To confirm or disprove these results, a phytase from Aspergillus niger 11T53A9 was purified and its enzymatic properties including the pathway of phytate dephosphorylation were determined.

\section{MATERIALS AND METHODS}

\section{Chemicals}

The Aspergillus niger strain 11T53A9 was obtained from the culture collection of Embrapa Agroindústria de Alimentos, Rio de Janerio. Most of the enzyme substrates were purchased from E. Merck (Darmstadt, Germany). Phytic acid, as a dodecasodium salt, was obtained from Aldrich (Steinheim,
Germany) and CM Sepharose CL 6B, DEAE Sepharose CL 6B, High load 16/60 Sephacryl S-200 HR, and Mono S HR 5/5 from Pharmacia (Freiburg, Germany). All reagents were of analytical grade. Ultrasep ES 100 RP18 was purchased from Bischoff (Leonberg, Germany) and HPIC column Carbo-Pac PA-100 was from Dionex (Sunnyvale, CA, USA). AG1 X-4, 100-200 mesh resin was obtained from Bio-Rad (München, Germany). The source of the myo-inositol phosphate standards were as indicated by Skoglund et al. (1998). The Pantoea agglomerans and Saccharomyces cerevisiae phytases were purified as described previously $(9,12)$.

\section{Growth of the fungus}

Aspergillus niger 11T53A9 was grown on wheat bran in Erlenmeyer flasks for $96 \mathrm{~h}$ at $30^{\circ} \mathrm{C}$. The initial moisture was adjusted to $60 \%$ and thereafter the medium was sterilized at $121^{\circ} \mathrm{C}$ for $15 \mathrm{~min}$, cooled and inoculated with $10^{7}$ spores per gram of fermentation medium.

\section{Preparation of the crude extract}

Enzyme extraction was carried out on a rotary shaker at $180 \mathrm{rpm}$ and $30^{\circ} \mathrm{C}$ for $1 \mathrm{~h}$ using $150 \mathrm{ml}$ of $0.1 \mathrm{M}$ acetate buffer, pH 5.0 per $40 \mathrm{~g}$ of fermentation medium. Insoluble material was removed by filtration and the clear extract was submitted to precipitation with 0-90\% ammonium sulfate and centrifuged at $5000 \mathrm{rpm}$ for $30 \mathrm{~min}$ at $4^{\circ} \mathrm{C}$.

\section{Protein determination}

Total protein concentration was determined by the Coomassie blue G-250 dye-binding assay using bovine serum albumin as a standard (1).

\section{Standard phytase assay}

Phytase activity was determined at $37^{\circ} \mathrm{C}$ in $350 \mu$ of 100 $\mathrm{mM}$ sodium acetate buffer, $\mathrm{pH} 5.0$ containing $875 \mathrm{nmol}$ sodium phytate. The enzymatic reaction was started by adding $10 \mu \mathrm{l}$ of enzyme solution to the assay mixture. After incubating for 30 $\min$ at $37^{\circ} \mathrm{C}$, the liberated phosphate was measured according to the ammonium molybdate method (13) with some 
modifications. Blanks were run by addition of the ammonium molybdate solution prior to addition of the enzyme solution to the assay mixture. One unit of enzyme activity was defined as the amount of enzyme that liberates $1 \mu \mathrm{mol}$ of inorganic phosphate per minute under the assay conditions.

To determine the substrate selectivity of the purified phytase, several phosphorylated compounds in addition to phytate were used for $K_{M}$ and $v_{\max }$ estimation. The incubation mixture consisted of $350 \mu \mathrm{L} 0.1 \mathrm{M}$ sodium acetate buffer, $\mathrm{pH}$ 5.0, containing the phosphorylated compound in a serial dilution of a concentrated stock solution $(10 \mathrm{mM})$. The enzymatic reactions were started by adding $10 \mu$ of enzyme to the assay mixtures. The rate of reaction was linear for the 30 min incubation time (data not shown). The kinetic constants $\left(\mathrm{K}_{\mathrm{M}}, \mathrm{v}_{\mathrm{max}}\right)$ were calculated from Lineweaver-Burk plots of the data.

To study the pH-optimum and the pH-stability of the purified phytase, the following buffers were used in the above described standard assay: $\mathrm{pH}$ 1.0-3.5, 0.1 M glycine-HCl; $\mathrm{pH}$ 3.5-6.0, 0.1 M sodium acetate-HCl; $\mathrm{pH}$ 6.0-7.0, 0.1 M Trisacetic acid; $\mathrm{pH}$ 7.0-9.0, 0.1 M Tris-HCl; pH 9.0-10.0, 0.1 M glycine- $\mathrm{NaOH}$.

\section{Effect of temperature on enzyme activity}

The temperature profile of the purified phytase was determined in the temperature range from 10 to $80^{\circ} \mathrm{C}$ using the standard phytase assay. To check thermal stability, the purified enzyme was incubated at different temperatures, cooled to $4^{\circ} \mathrm{C}$, and assayed using the standard phytase assay.

\section{Effect of cations and potential inhibitors on enzyme activity}

The effect of cations and potential inhibitors on enzyme activity was investigated by pre-incubating the compounds with the purified phytase for $15 \mathrm{~min}$ at $37^{\circ} \mathrm{C}$ before the standard phytase assay was performed. The following cations and potential inhibitors were used in concentrations of $0.1 \mathrm{mM}, 0.2$ $\mathrm{mM}, 0.5 \mathrm{mM}, 0.8 \mathrm{mM}$ and $1.0 \mathrm{mM}: \mathrm{Mg}^{2+}, \mathrm{Ca}^{2+}, \mathrm{Mn}^{2+}, \mathrm{Fe}^{2+}$, $\mathrm{Fe}^{3+}, \mathrm{Cu}^{2+}, \mathrm{Zn}^{2+}$, o-phenanthroline, EDTA, citrate, tartrate, 2mercaptoethenol, azide, arsenate, molybdate, wolframate, and vanadate. Fluoride and phosphate were used in the range 0.02 $\mathrm{mM}-1.0 \mathrm{mM}$.

\section{Preparation of myo-inositol pentakis- and trisphosphate isomers \\ $50 \mu \mathrm{mol} m y o$-inositol hexakisphosphate in the} corresponding incubation buffer were incubated at $37^{\circ} \mathrm{C}$ with $0.4 \mathrm{U}$ of the phytases in a final volume of $20 \mathrm{ml}$. After an incubation period of 60 minutes (myo-inositol pentakisphosphate preparation) or 8 hours (myo-inositol trisphosphate preparation), respectively, the reactions were stopped by heat treatment $\left(95^{\circ} \mathrm{C}, 10 \mathrm{~min}\right)$. The incubation mixtures were lyophilised and the dry residues were dissolved in $10 \mathrm{ml} 0.2 \mathrm{M}$ ammonium formate, $\mathrm{pH}$ 2.5. The solutions were loaded onto a Q-Sepharose column $(2.6$ x $90 \mathrm{~cm})$ equilibrated with $0.2 \mathrm{M}$ ammonium formate, $\mathrm{pH} 2.5$ at a flow rate of $2.5 \mathrm{ml}$ $\min ^{-1}$. The column was washed with $500 \mathrm{ml}$ of $0.2 \mathrm{M}$ ammonium formate, $\mathrm{pH} \mathrm{2.5;}$ the bound myo-inositol trisphosphates were eluted with a linear gradient from 0.2 to 0.6 $\mathrm{M}$ ammonium formate, $\mathrm{pH} 2.5(1000 \mathrm{ml})$ and the bound myoinositol pentakisphosphates with a linear gradient from 1.0 to 1.4 $\mathrm{M}$ ammonium formate, $\mathrm{pH} 2.5(1000 \mathrm{ml})$ at $2.5 \mathrm{ml} \mathrm{min}^{-1} .10$ $\mathrm{ml}$ fractions were collected. From even-numbered tubes, $100 \mu \mathrm{l}$ aliquots were lyophilised. The liberated phosphate was quantified by a modification of the ammonium molybdate method (13). The content of the fraction tubes corresponding to the myo-inositol tris- and pentakisphosphates, respectively, were pooled and lyophilised until only a dry residue remained. Ten milliliters of water were used to redissolve the residues. Lyophilisation and redissolving were repeated twice to completely remove ammonium formate. Myo-inositol phosphate concentrations were determined by HPLC ion-pair chromatography on Ultrasep ES 100 RP18 ( 2 x 250 mm). The column was run at $45^{\circ} \mathrm{C}$ and $0.2 \mathrm{ml} \min ^{-1}$ of an eluant consisting of formic acid:methanol:water:TBAH (tetrabutylammonium hydroxide) (44:56:5:1.5 v/v), pH 4.25, as described by Sandberg and Ahderinne (20). A mixture of the individual myo-inositol phosphate esters $\left(\mathrm{InsP}_{3}-\mathrm{InsP}_{6}\right)$ was used as a standard. The purity of the myo-inositol phosphate 
preparations was determined on a High-Performance Ion Chromatography system as described by Skoglund et al. (23).

\section{Production of enzymatically formed hydrolysis products}

The enzymatic reaction was started at $37^{\circ} \mathrm{C}$ by addition of $50 \mu \mathrm{l}$ of a suitable diluted solution of the phytase from Aspergillus niger 11T53A9 to the incubation mixtures $\left(1 \mathrm{U} \mathrm{ml}^{-}\right.$ $\left.{ }^{1}\right)$. The incubation mixture consisted of $1250 \mu 10.1 \mathrm{M}$ sodium acetate buffer, pH 5.0 containing $3.125 \mu$ mol sodium phytate. From the incubation mixture, $150 \mu \mathrm{l}$ samples were removed periodically and the reaction was stopped by heat treatment $\left(95^{\circ} \mathrm{C}, 10 \mathrm{~min}\right)$. For the identification of phytate degradation products, $50 \mu \mathrm{l}$ of the heat-treated samples were chromatographed on a High-Performance Ion Chromatography system as described by Skoglund et al. (23).

\section{Identification of enzymatically formed hydrolysis products}

Myo-Inositol phosphate isomers were determined and separated on a HPIC system using a Carbo Pac PA-100 (4 x $250 \mathrm{~mm})$ analytical column and a gradient of 5-98\% $\mathrm{HCl}(0.5$ M, $0.8 \mathrm{ml} \mathrm{min}^{-1}$ ) as described by Skoglund et al. (23). The eluants were mixed in a post-column reactor with $0.1 \%$ $\mathrm{Fe}\left(\mathrm{NO}_{3}\right)_{3} \times 9 \mathrm{H}_{2} \mathrm{O}$ in a $2 \%(\mathrm{v} / \mathrm{v}) \mathrm{HClO}_{4}$ solution $\left(0.4 \mathrm{ml} \mathrm{min}^{-1}\right)$ according to Phillippy and Bland (19). The combined flow rate was $1.2 \mathrm{ml} \mathrm{min}^{-1}$.

\section{Quantification of the liberated phosphate}

The liberated phosphate was quantified by a modification of the ammonium molybdate method (13). $1.5 \mathrm{ml}$ of a freshly prepared solution of acetone:2.5 M sulfuric acid:10 mM ammonium molybdate $(2: 1: 1 \mathrm{v} / \mathrm{v})$ and thereafter $100 \mu 11.0 \mathrm{M}$ citric acid were added to $400 \mu \mathrm{l}$ of the suitably diluted hydrolysis mixtures or to the mixtures of the phytase assay. Any cloudiness was removed by centrifugation prior to the measurement of absorbance at $355 \mathrm{~nm}$. In order to quantify the released phosphate a calibration curve was produced over the range of 5 to $600 \mathrm{nmol}$ phosphate.

\section{Identification of the myo-inositol monophosphate isomer}

Myo-inositol monophosphates were produced by incubation of $1.0 \mathrm{U}$ of the phytase from the purified phytase with a limiting amount $(0.1 \mu \mathrm{mol})$ of phytate in a final volume of $500 \mu \mathrm{l}$ of $50 \mathrm{mM}$ ammonium formate. After lyophilisation, the residues were dissolved in $500 \mu \mathrm{l}$ of a solution of pyridine:bis(trimethylsilyl)trifluoroacetamide (1:1 $\mathrm{v} / \mathrm{v}$ ) and incubated at room temperature for $24 \mathrm{~h}$. The silylated products were injected at $270^{\circ} \mathrm{C}$ into a gas chromatograph coupled with a mass spectrometer. The stationary phase was methylsilicon in a fused silica column $(0.25 \mathrm{~mm} \times 15 \mathrm{~m})$. Helium was used as the carrier gas at a flow rate of $0.5 \mathrm{~m} \mathrm{~s}^{-1}$. The following heating program was used for the column: $100^{\circ} \mathrm{C}$ to $340^{\circ} \mathrm{C}$, rate increase: $4^{\circ} \mathrm{C} \mathrm{min}^{-1}$. Ionisation was performed by electron impact at $70 \mathrm{eV}$ and $250^{\circ} \mathrm{C}$.

\section{Purification of the phytate-degrading enzyme}

The FPLC was run at $25^{\circ} \mathrm{C}$ and a flow rate of $1 \mathrm{ml} \mathrm{min}^{-1}$. Normal pressure chromatography was performed at $4{ }^{\circ} \mathrm{C}$.

\section{Ammonium sulfate precipitation}

The clarified enzyme extract was used for an ammonium sulfate precipitation at $0-90 \%$ saturation. The precipitate was suspended in $20 \mathrm{mM}$ Tris-HCl buffer, $\mathrm{pH} 7.0$ and dialyzed against the same buffer. Any insoluble material was removed by centrifugation.

\section{DEAE-Sepharose CL 6B chromatography}

The dialysed $90 \%$ ammonium sulfate precipitate was loaded onto DEAE-Sepharose CL 6B column (3 x $15 \mathrm{~cm}$ ) equilibrated with $20 \mathrm{mM}$ Tris- $\mathrm{HCl}$ buffer, $\mathrm{pH}$ 7.0. After eluting the unbound inactive protein from the column with equilibration buffer, a linear gradient of 0 to $0.5 \mathrm{M} \mathrm{NaCl}$ (1000 $\mathrm{ml}$ ) in $20 \mathrm{mM}$ Tris- $\mathrm{HCl}$ buffer, $\mathrm{pH} 7.0$ was applied. The fractions containing phytate-degrading activity were pooled and dialysed against $20 \mathrm{mM}$ glycine- $\mathrm{HCl}$ buffer, $\mathrm{pH} 2.85$.

\section{CM-Sepharose CL 6B chromatography}

The dialysed pool from the previous step was loaded onto a CM-Sepharose CL 6B column $(3.5 \times 20 \mathrm{~cm})$ equilibrated with 
$20 \mathrm{mM}$ glycine- $\mathrm{HCl}$ buffer, $\mathrm{pH}$ 2.85. The column was washed with $300 \mathrm{ml}$ of the same buffer and then the proteins bound were eluted with a linear gradient from 0 to $1.0 \mathrm{M} \mathrm{NaCl}(1000$ $\mathrm{ml}$ ) in $20 \mathrm{mM}$ glycine- $\mathrm{HCl}$ buffer, $\mathrm{pH}$ 4.5. The fractions containing phytate-degrading activity were pooled.

\section{6/60 Sephacryl S-200 HR chromatography}

The phytate-degrading enzyme-containing fractions from the previous step were loaded onto a 16/60 Sephacryl S-200 HR column equilibrated with $50 \mathrm{mM}$ sodium acetate buffer, $\mathrm{pH}$ 5.0, containing $0.2 \mathrm{M} \mathrm{NaCl}$. The maximum loading volume per run was $2 \mathrm{ml} .2 \mathrm{ml}$ fractions were collected. The fractions containing phytate-degrading activity were pooled and dialysed against $20 \mathrm{mM}$ sodium acetate buffer, $\mathrm{pH}$ 5.0.

\section{Mono S HR 5/5 chromatography}

The dialysed fraction from the previous step was applied onto a Mono S HR 5/5 column equilibrated with $20 \mathrm{mM}$ sodium acetate buffer, $\mathrm{pH}$ 5.0. The column was washed with equilibration buffer for $30 \mathrm{~min}$ and then with a linear gradient of 0 to $0.5 \mathrm{M} \mathrm{NaCl}$ in $20 \mathrm{mM}$ sodium acetate buffer, $\mathrm{pH} 5.0$, for $60 \mathrm{~min}$. $2.5 \mathrm{ml}$ fractions were collected. The fractions containing phytate-degrading activity were pooled.

\section{Gel electrophoresis}

Table 1. Purification scheme for the phytate-degrading enzyme from Aspergillus niger

\begin{tabular}{|c|c|c|c|c|c|}
\hline purification step & $\begin{array}{c}\text { total protein } \\
\qquad(\mu \mathrm{g})\end{array}$ & $\begin{array}{l}\text { total phytate- } \\
\text { degrading activity } \\
\text { (U) }\end{array}$ & $\begin{array}{l}\text { Specific activity } \\
\left.\text { (U mg }{ }^{-1}\right)\end{array}$ & $\begin{array}{l}\text { purification } \\
\text { (fold) }\end{array}$ & $\begin{array}{c}\text { recovery } \\
(\%)\end{array}$ \\
\hline Crude extract & 54000 & 138 & 2.6 & - & - \\
\hline $0-90 \%\left(\mathrm{NH}_{4}\right)_{2} \mathrm{SO}_{4}$ precipitation & 26539 & 117 & 4.4 & 1.7 & 84.8 \\
\hline DEAE Sepharose CL6B & 5693 & 110 & 19.3 & 7.4 & 79.7 \\
\hline CM Sepharose CL 6B & 1156 & 62 & 53.6 & 20.6 & 44.9 \\
\hline Sephacryl S-200 HR & 287 & 36 & 125.4 & 48.2 & 26.1 \\
\hline Mono S HR 5/5 & 211 & 28 & 132.7 & 51.0 & 20.3 \\
\hline
\end{tabular}

The SDS-electrophoresis using $10 \%$ gels was performed according to Laemmli (16). Gels were stained by Coomassie brilliant blue R-250.

\section{Gel-filtration}

To assess the molecular mass of the native phytase, the purified protein was gel-filtered on 16/60 Sephacryl S-200 HR equilibrated with $50 \mathrm{mM}$ sodium acetate buffer, $\mathrm{pH}$ 5.0, containing $0.2 \mathrm{M} \mathrm{NaCl}$. The column was calibrated with glucose-6-phosphate dehydrogenase $\left(M_{r}=120,000\right)$, creatine kinase $\left(M_{r}=81,000\right)$, bovine serum albumin $\left(M_{r}=68,000\right)$, $\beta$ lactoglobulin $\left(M_{r}=40,000\right)$, and myoglobin $\left(M_{r}=17,000\right)$.

\section{Statistical methods}

The Student's $t$ test was used for statistical comparison.

\section{RESULTS}

\section{Purification of the phytase}

A summary of the purification scheme is given in Table 1. The phytase activity was eluted as a single sharp activity peak from each ion-exchange column after application of the gradient. A 51-fold purification of the enzyme was achieved with a recovery of $20.3 \%$. The enzyme exhibited an activity of about $133 \mathrm{U} \mathrm{mg}^{-1}$. 


\section{Molecular properties}

Gel filtration of the native enzyme on a calibrated Sephacryl S-200 column gave a molecular mass of the phytase of $85,000 \pm 2,500 \mathrm{Da}$ with elution position being measured by determination of enzyme activity (figure 1). Lower molecular mass species or higher molecular mass aggregates were not observed. The phytase preparation gave a single broad protein band upon SDS gel electrophoresis after Coomassie staining of the gels (data not shown). This result indicates that the phytase could be regarded as homogeneous. According to the estimated molecular masses after SDS-PAGE, the protein band corresponds to a molecular mass of 85,000 Da. Consequently, this enzyme is a monomeric protein.

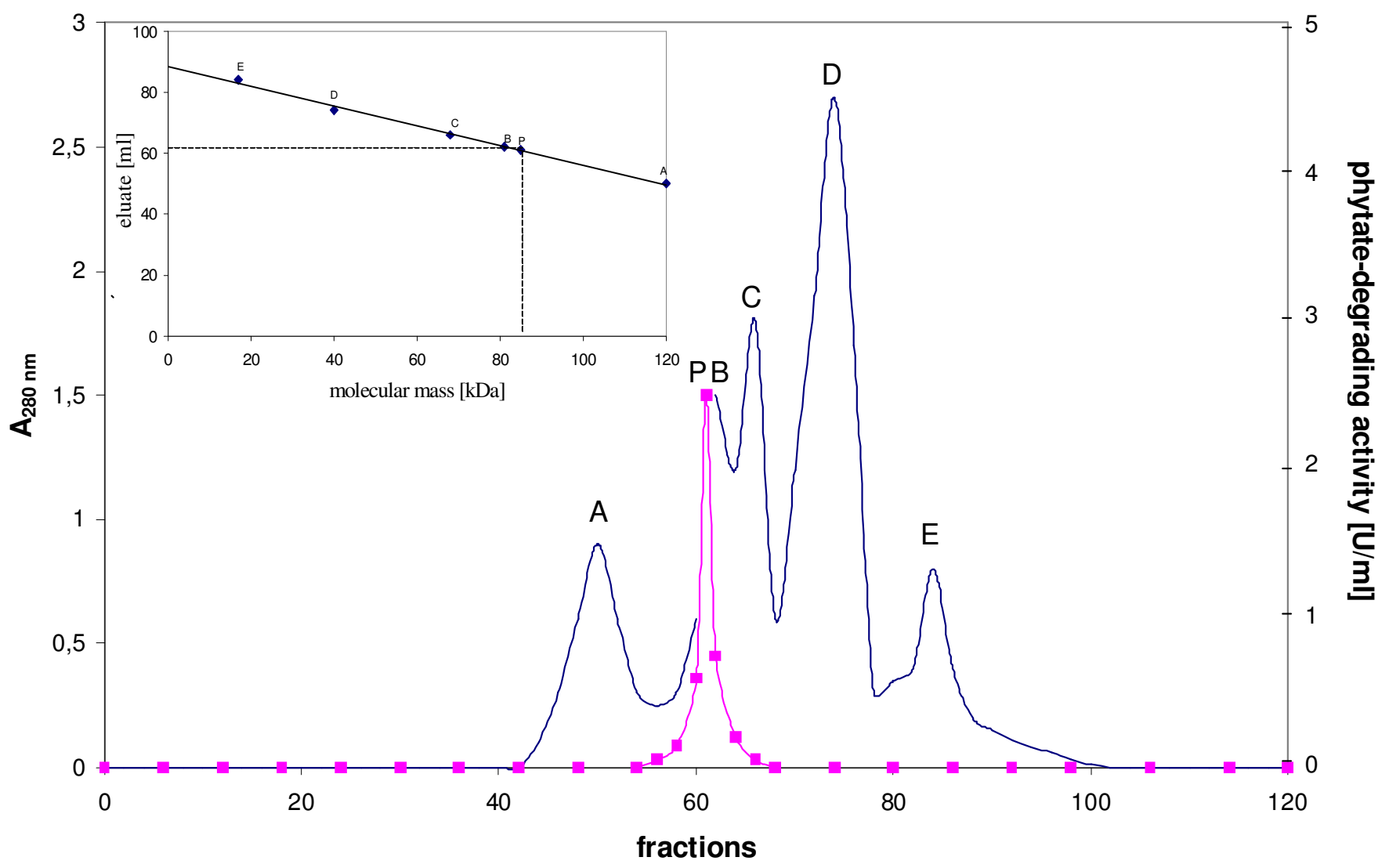

Figure 1. Estimation of the molecular mass of the phytate-degrading enzyme from Aspergillus niger by gel filtration.

The column was calibrated with A: glucose-6-phosphate dehydrogenase $\left(M_{r}=120,000\right)$, B: creatine kinase $\left(M_{r}=81,000\right)$, C: bovine serum albumin $\left(M_{r}=68,000\right)$, D: B-lactoglobulin $\left(M_{r}=40,000\right)$, and E: myoglobin $\left(M_{r}=17,000\right)$. P: phytate-degrading enzyme from Aspergillus niger ( $\mathrm{M}_{\mathrm{r}}$ estimated to be approximately 85,000). Phytate-degrading activity ( - ), optical density at 280 $\mathrm{nm}(-)$

\section{Enzymatic properties}

\section{pH optimum and pH stability}

The standard phytase assay was performed using a variety of buffers from $\mathrm{pH} 1.0$ to 9.0. Two distinct $\mathrm{pH}$ optima were identified; the highest activity was recorded at pH 5.0 and the second activity peak occurred at $\mathrm{pH} 2.8$. The activity at $\mathrm{pH} 5.0$ was 1.5 fold higher than at $\mathrm{pH} 2.8$. The enzyme was virtually inactive above $\mathrm{pH}$ 7.0. The effect on enzyme stability was studied in the $\mathrm{pH}$ range 1.0 to 9.0 at $4^{\circ} \mathrm{C}$. Within 14 days the phytase did not lose any activity in the $\mathrm{pH}$ range from 3.0 to 8.0. The purified enzyme is also stable at low $\mathrm{pH}$ values, retaining full activity after incubation at $\mathrm{pH} 2$ for $24 \mathrm{~h}$ at $4{ }^{\circ} \mathrm{C}$ 
and $95 \%$ after incubation at $\mathrm{pH} 2.0$ at $37^{\circ} \mathrm{C}$.

\section{Temperature optimum and thermal stability}

The temperature profile of the purified phytase was determined from 10 to $80^{\circ} \mathrm{C}$ using the standard phytase assay. The temperature optimum was found to be $55^{\circ} \mathrm{C}$. The apparent activation energy was estimated at pH 5.0 from the slope of $\log$ $\mathrm{v}_{\max }$ versus $1 / \mathrm{T}$. The data showed excellent linearity from 15 to $50^{\circ} \mathrm{C}$. The Arrhenius activation energy for the hydrolysis of phytate was calculated to be $39.1 \mathrm{~kJ} \mathrm{~mol}^{-1}$. In order to check thermal stability, the purified enzyme was incubated at different temperatures, cooled to $4^{\circ} \mathrm{C}$ and assayed using the standard phytase assay. The enzyme lost no activity in $10 \mathrm{~min}$ at temperatures up to $55^{\circ} \mathrm{C}$. When exposed for $10 \mathrm{~min}$ at $70^{\circ} \mathrm{C}$, it retained $45 \%$ and at $80^{\circ} \mathrm{C}$ for $5 \mathrm{~min} 8 \%$ of the initial activity.

\section{Substrate selectivity and kinetic parameters}

In order to determine the substrate selectivity of the purified phytase, several phosphorylated compounds (ATP, ADP, AMP, pNPP, phenylphosphate, glucose-1-phosphate, 1- naphthyl phosphate, 2-naphthyl phosphate, 2-glycero phosphate), in addition to phytate, were used for $K_{M}$ and $v_{\max }$ estimation by detecting the release of the phosphate ion during hydrolysis using formation of a soluble phospho-molybdate complex in an acidic water-acetone mixture (table 2). Phytate was identified as a good substrate. All other compounds tested were only marginally hydrolysed by the purified enzyme. Of all compounds tested, phytate gave the highest $\mathrm{k}_{\text {cat }} / \mathrm{K}_{\mathrm{M}}$-value. Therefore, under physiological conditions the likely substrate for the Aspergillus niger 11T53A9 phytase is phytate. The kinetic parameters for the hydrolysis of phytate were determined to be $\mathrm{K}_{\mathrm{M}}=54 \mu \mathrm{mol} \mathrm{l}^{-1}$ and $\mathrm{k}_{\text {cat }}=190 \mathrm{sec}^{-1}$ at $\mathrm{pH} 5.0$ and $37^{\circ} \mathrm{C}$. Like other fungal phytases, the purified enzyme showed a substrate inhibition (15). The activity of the purified enzyme was inhibited at substrate concentrations $>2.5 \mathrm{mM}$ at $\mathrm{pH}$ 5.0. The maximum amount of phosphate released from phytate by the purified enzyme suggests myo-inositol monophosphate as the final product of enzymatic phytate degradation.

Table 2. Kinetic constants for the hydrolysis of phosphorylated compounds by the phytate-degrading enzyme from Aspergillus niger at $\mathrm{pH} 5.0$
substrate
$\mathbf{K}_{\mathbf{M}}(\boldsymbol{\mu M})$
$\mathbf{k}_{\text {cat }}\left(\sec ^{-1}\right)$
$\mathbf{k}_{\mathrm{cat}} / \mathbf{K}_{\mathrm{M}}\left(\mathbf{s}^{-1} \mathbf{M}^{-1}\right)$

$\begin{array}{lrrr}\text { phytate } & 54 \pm 1.4 & 190 \pm 4.3 & 3518519 \\ \text { p-nitrophenyl phosphate } & 124 \pm 3.9 & 35 \pm 0.9 & 282258 \\ \text { 1-naphthyl phosphate } & 247 \pm 6.7 & 23 \pm 1.5 & 93117 \\ \text { 2-naphthyl phosphate } & 276 \pm 7.1 & 22 \pm 1.3 & 79710 \\ \text { 2-glycero phosphate } & 521 \pm 9.1 & 9 \pm 0.3 & 17274 \\ \text { AMP } & 497 \pm 8.2 & 11 \pm 1.1 & 22133 \\ \text { ADP } & 534 \pm 7.9 & 12 \pm 0.9 & 22472 \\ \text { ATP } & 587 \pm 6.5 & 8 \pm 0.6 & 13629 \\ \text { Glucose-1-phosphate } & 741 \pm 6.4 & 6 \pm 0.4 & 8097 \\ \text { Phenyl phosphate } & 177 \pm 1.3 & 36 \pm 1.7 & 203390\end{array}$

Temperature: $37^{\circ} \mathrm{C}$; buffer: $100 \mathrm{mM}$ sodium acetate, $\mathrm{pH} 5.0$; enzyme concentration: $25 \mathrm{mU} \mathrm{ml}^{-1}$. The data are mean values of five independent experiments. 


\section{Effector studies}

None of the metal ions used in the study had an activating effect when used at a concentration between $10^{-4}$ and $10^{-3} \mathrm{M}$. $\mathrm{Mg}^{2+}, \mathrm{Ca}^{2+}, \mathrm{Mn}^{2+}, \mathrm{Co}^{2+}, \mathrm{Ag}^{+}, \mathrm{Hg}^{2+}, \mathrm{Cu}^{2+}$ had little or no effect on enzyme activity, while $\mathrm{Zn}^{2+}, \mathrm{Fe}^{2+}$, and $\mathrm{Fe}^{3+}$ showed strong inhibitory effects. The reduced phytase activity in the presence of $\mathrm{Fe}^{2+}$ and $\mathrm{Fe}^{3+}$ is attributed to a lower phytate concentration in the enzyme assay because of the appearance of a Fe-phytate precipitate. When compounds which tend to chelate metal ions, such as $o$-phenanthroline, EDTA, oxalate, citrate or tartrate, were tested for their effect on enzyme activity, it was noted that none of them was inhibitory at a concentration from $10^{-4}$ to $10^{-3}$ M. Fluoride, a known inhibitor of different phytases from different origin (15) and the hydrolysis product phosphate as well as its structural analogous molybdate, wolframate and vanadate were found to be strong inhibitors of the purified enzyme. Fluoride inhibited the hydrolysis of phytate with a $\mathrm{K}_{\mathrm{i}}$ value of $158 \mu \mathrm{mol} \mathrm{l}^{-1}$.

\section{Phytate dephosphorylation pathway}

Intermediates of enzymatic myo-inositol hexakisphosphate dephosphorylation

Identification of the hydrolysis products of myo-inositol hexakisphosphate generated by the Aspergillus niger 11T53A9 phytase was performed by HPIC analysis (figure 2). The chromatographic profile of the zero-time control indicated only the myo-inositol hexakisphosphate peak. After 30 minutes of incubation, the quantity of myo-inositol hexakisphosphate had decreased and $\mathrm{D} / \mathrm{L}-\operatorname{Ins}(1,2,4,5,6) \mathrm{P}_{5}$ appeared as the major degradation product, accompanied by significant amounts of $\mathrm{D} / \mathrm{L}-\mathrm{Ins}(1,2,5,6) \mathrm{P}_{4}$ and low amounts of $\mathrm{D} / \mathrm{L}-\operatorname{Ins}(1,2,6) \mathrm{P}_{3} /$ $\operatorname{Ins}(1,2,3) \mathrm{P}_{3}$. After 60 minutes of incubation, $\mathrm{D} / \mathrm{L}-\operatorname{Ins}(1,2,5,6) \mathrm{P}_{4}$ was the major myo-inositol phosphate present in the incubation mixture. In addition, significant amounts of $\mathrm{D} / \mathrm{L}-\operatorname{Ins}(1,2,6) \mathrm{P}_{3} /$ $\operatorname{Ins}(1,2,3) \mathrm{P}_{3}$ and low amounts of D/L-Ins(1,2) $\mathrm{P}_{2} / \operatorname{Ins}(2,5) \mathrm{P}_{2} /$ D/L-Ins(4,5) $\mathrm{P}_{2}$ appeared. After 90 minutes of incubation, myoinositol hexakis- and myo-inositol pentakisphosphate were completely degraded to D/L-Ins(1,2,5,6) $\mathrm{P}_{4}, \mathrm{D} / \mathrm{L}-\operatorname{Ins}(1,2,6) \mathrm{P}_{3} /$ $\operatorname{Ins}(1,2,3) \mathrm{P}_{3}$, and $\mathrm{D} / \mathrm{L}-\operatorname{Ins}(1,2) \mathrm{P}_{2} / \operatorname{Ins}(2,5) \mathrm{P}_{2} / \mathrm{D} / \mathrm{L}-\operatorname{Ins}(4,5) \mathrm{P}_{2}$.
After 120 minutes of incubation only the myo-inositol tris- and bisphosphate peaks remained. Because all theoretically existing myo-inositol pentakis- and tetrakisphosphate isomers are well resolved on the high performance ion chromatography system used, identity of the myo-inositol pentakis- and tetrakisphosphate isomers formed by the Aspergillus niger 11T53A9 phytase as D/L-Ins $(1,2,4,5,6) \mathrm{P}_{5}$ and $\mathrm{D} / \mathrm{L}-$ Ins $(1,2,5,6) \mathrm{P}_{4}$ is well established. A clear identification of the generated myo-inositol tris-, bis- and monophosphate isomers by high performance ion chromatography was not possible, because not all theoretically existing isomers were available.

\section{Identification of the absolute configuration of the predominantly generated myo-inositol pentakisphosphate} isomer

To determine the absolute configuration of the myo-inositol pentakisphosphate isomer generated predominantly by the phytase from Aspergillus niger 11T53A9, kinetic studies with the purified myo-inositol pentakisphosphate isomers generated either by the phytases from Pantoea agglomerans and the phytase from Aspergillus niger 11T53A9 were performed. The enzymes were added to sequentially diluted solutions of the purified myo-inositol pentakisphosphate isomers and the kinetic parameters $\left(\mathrm{K}_{\mathrm{M}}, \mathrm{k}_{\mathrm{cat}}\right)$ were calculated from the LineweaverBurk plots of the data (table 3 ). $\mathrm{K}_{\mathrm{M}}$ and $\mathrm{k}_{\mathrm{cat}}$ for enzymatic hydrolysis of the major myo-inositol pentakisphosphate isomer generated by the Aspergillus niger 11T53A9 and Pantoea agglomerans phytases were almost identical. Since it is known that the Pantoea agglomerans phytase generates the D$\operatorname{Ins}(1,2,4,5,6) \mathrm{P}_{5}$ isomer (10), D-Ins $(1,2,4,5,6) \mathrm{P}_{5}$ and $\mathrm{D}$ Ins $(1,2,5,6) \mathrm{P}_{4}$ were the first two predominant breakdown products of myo-inositol hexakisphosphate dephosphorylation by the phytase from Aspergillus niger 11T53A9.

\section{Identification of the myo-inositol monophosphates formed}

The end product of the enzymatic dephosphorylation of phytate was received by incubation of the Aspergillus niger 11T53A9 phytase with a limiting amount of myo-inositol hexakisphosphate. It was identified by gas chromatography- 
mass spectrometry as Ins(2)P (data not shown).

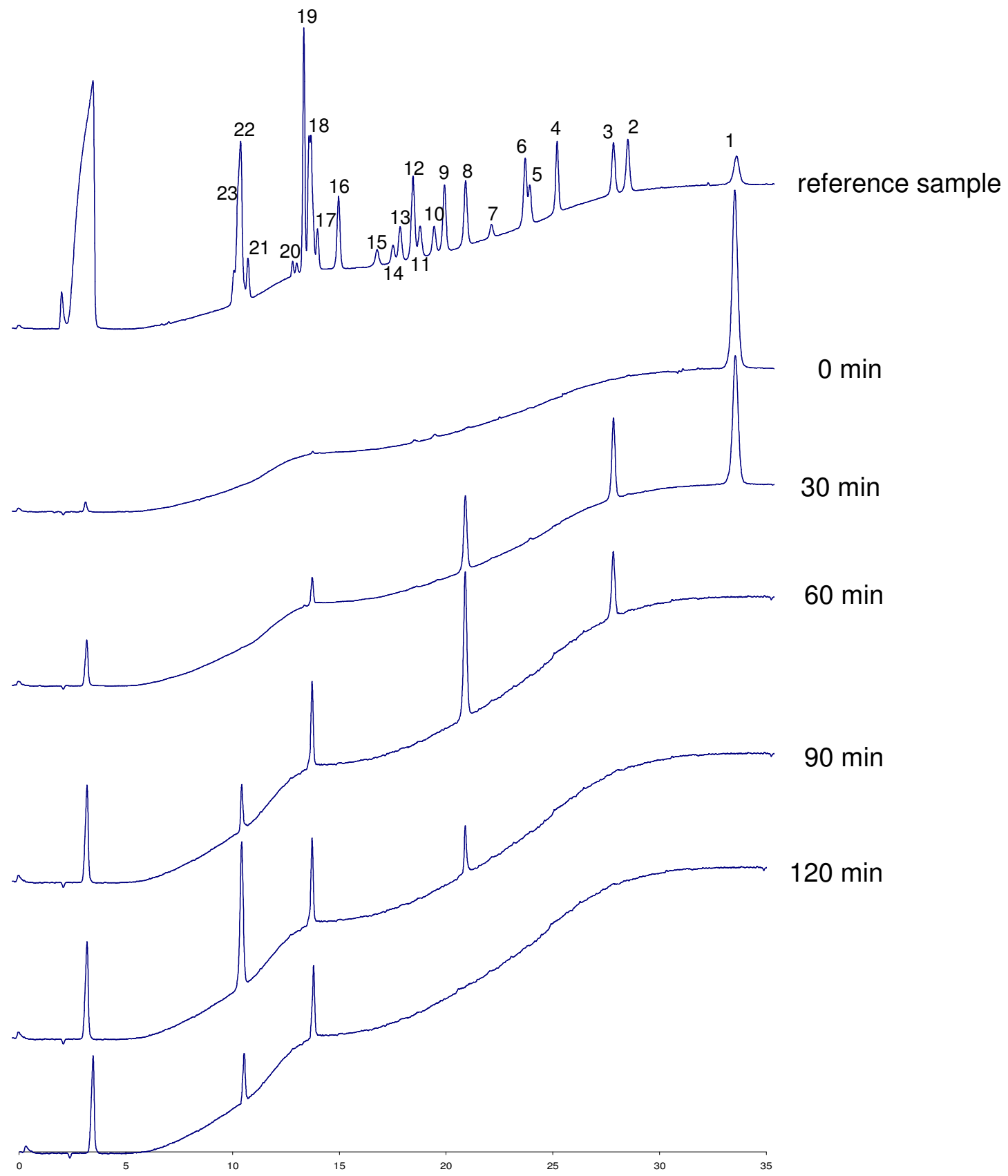

Figure 2. High performance ion chromatography analysis of hydrolysis products of phytate by an apparently pure phytatedegrading enzyme from Aspergillus niger

Reference sample: The source of the reference myo-inositol phosphates is as indicated in Skoglund et al. (23); Peaks: (1) $\operatorname{Ins}(1,2,3,4,5,6) \mathrm{P}_{6} ; \quad$ (2) $\operatorname{Ins}(1,3,4,5,6) \mathrm{P}_{5} ; \quad$ (3) $\mathrm{D} / \mathrm{L}-\operatorname{Ins}(1,2,4,5,6) \mathrm{P}_{5} ; \quad$ (4) $\mathrm{D} / \mathrm{L}-\operatorname{Ins}(1,2,3,4,5) \mathrm{P}_{5} ; \quad(5) \quad \operatorname{Ins}(1,2,3,4,6) \mathrm{P}_{5} ; \quad(6) \quad \mathrm{D} / \mathrm{L}-$ $\operatorname{Ins}(1,4,5,6) \mathrm{P}_{4} ;(7) \operatorname{Ins}(2,4,5,6) \mathrm{P}_{4} ;(8) \mathrm{D} / \mathrm{L}-\operatorname{Ins}(1,2,5,6) \mathrm{P}_{4} ;$ (9) D/L-Ins(1,3,4,5) $\mathrm{P}_{4} ;(10) \mathrm{D} / \mathrm{L}-\operatorname{Ins}(1,2,4,5) \mathrm{P}_{4} ;(11) \operatorname{Ins}(1,3,4,6) \mathrm{P}_{4} ;(12)$ $\mathrm{D} / \mathrm{L}-\operatorname{Ins}(1,2,3,4) \mathrm{P}_{4} ;(13) \mathrm{D} / \mathrm{L}-\operatorname{Ins}(1,2,4,6) \mathrm{P}_{4} ;(14) \operatorname{Ins}(1,2,3,5) \mathrm{P}_{4} ;(15) \operatorname{Ins}(4,5,6) \mathrm{P}_{3} ;(16) \mathrm{D} / \mathrm{L}-\operatorname{Ins}(1,5,6) \mathrm{P}_{3} ;(17) \mathrm{D} / \mathrm{L}-\operatorname{Ins}(1,4,5) \mathrm{P}_{3}$; (18) $\mathrm{D} / \mathrm{L}-\operatorname{Ins}(1,2,6) \mathrm{P}_{3}, \operatorname{Ins}(1,2,3) \mathrm{P}_{3} ;(19) \mathrm{D} / \mathrm{L}-\operatorname{Ins}(1,3,4) \mathrm{P}_{3} ; \quad$ (20) $\mathrm{D} / \mathrm{L}-\operatorname{Ins}(1,2,4) \mathrm{P}_{3}$, (21) $\mathrm{D} / \mathrm{L}-\operatorname{Ins}(2,4) \mathrm{P}_{2} ; \quad(22) \quad \mathrm{D} / \mathrm{L}-\operatorname{Ins}(1,2) \mathrm{P}_{2}$, $\operatorname{Ins}(2,5) \mathrm{P}_{2}, \mathrm{D} / \mathrm{L}-\operatorname{Ins}(4,5) \mathrm{P}_{2} ;(23) \mathrm{D} / \mathrm{L}-\operatorname{Ins}(1,4) \mathrm{P}_{2}, \mathrm{D} / \mathrm{L}-\operatorname{Ins}(1,6) \mathrm{P}_{2}$. 
Table 3. Kinetic constants for enzymatic myo-inositol pentakisphosphate dephosphorylation

\section{InsP 5 generated by}

\begin{tabular}{llll} 
phytase & \multicolumn{1}{c}{ kinetic constant } & $\begin{array}{c}\text { Aspergillus niger } \\
\text { phytase }\end{array}$ & $\begin{array}{c}\text { Pantoea agglomerans } \\
\text { phytase }\end{array}$ \\
\hline Aspergillus niger & $\mathrm{K}_{\mathrm{M}}\left[\mu \mathrm{mol} \mathrm{l}^{-1}\right]$ & $156 \pm 12^{\mathrm{a}}$ & $159 \pm 12^{\mathrm{a}}$ \\
& $\mathrm{k}_{\mathrm{cat}}\left[\mathrm{s}^{-1}\right]$ & $140 \pm 12^{\mathrm{a}}$ & $136 \pm 7^{\mathrm{a}}$ \\
Pantoea agglomerans & $\mathrm{K}_{\mathrm{M}}\left[\mu \mathrm{mol} \mathrm{l}^{-1}\right]$ & $154 \pm 5^{\mathrm{a}}$ & $155 \pm 10^{\mathrm{a}}$ \\
& $\mathrm{k}_{\mathrm{cat}}\left[\mathrm{s}^{-1}\right]$ & $141 \pm 11^{\mathrm{a}}$ & $139 \pm 9^{\mathrm{a}}$
\end{tabular}

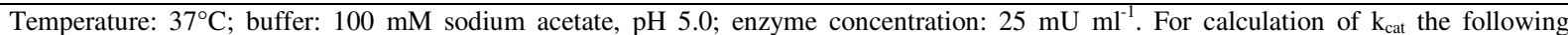
molecular masses were used: Aspergillus niger, $85 \mathrm{kDa}$, Pantoea agglomerans, $42 \mathrm{kDa}(9)$. The data are mean values of five independent experiments. ${ }^{a}$ means within the same line with the same superscripts are not significantly different $(\mathrm{P}<0.05)$

\section{Elucidation of the major phytate degradation pathway}

In consideration of $\operatorname{Ins}(2) \mathrm{P}$ as the final degradation product, dephosphorylation of $\mathrm{D}$-Ins $(1,2,5,6) \mathrm{P}_{4}$ may yield $\mathrm{D}$ $\operatorname{Ins}(1,2,5) \mathrm{P}_{3}, \quad \mathrm{D}-\operatorname{Ins}(1,2,6) \mathrm{P}_{3}$ and $\mathrm{D}-\operatorname{Ins}(2,5,6) \mathrm{P}_{3}$ as a myoinositol trisphosphate intermediate and $\mathrm{D}-\operatorname{Ins}(1,2) \mathrm{P}_{2}, \mathrm{D}$ $\operatorname{Ins}(2,5) \mathrm{P}_{2}$ and $\mathrm{D}-\operatorname{Ins}(2,6) \mathrm{P}_{2}$ as a myo-inositol bisphosphate isomer. According to High-Performance Ion Chromatography, $\mathrm{D}-\operatorname{Ins}(2,5,6) \mathrm{P}_{3}$ and $\mathrm{D}-\operatorname{Ins}(2,6) \mathrm{P}_{2}$ have to be excluded as intermediates, since these myo-inositol phosphates elute well resolved from the $\mathrm{InsP}_{3}$ and $\mathrm{InsP}_{2}$ peaks, respectively, generated during myo-inositol hexakisphosphate dephosphorylation by the Aspergillus niger 11T53A9 phytase. It is not possible to discriminate between D-Ins $(1,2) \mathrm{P}_{2}$ and D-Ins $(2,5) \mathrm{P}_{2}$, since these two isomers co-elute on the High-Performance Ion chromatography system used. In addition, the discrimination between D-Ins $(1,2,5) \mathrm{P}_{3}$ and $\mathrm{D}-\operatorname{Ins}(1,2,6) \mathrm{P}_{3}$ is impossible, since pure D-Ins $(1,2,5) \mathrm{P}_{3}$ is not available. To determine the absolute configuration of the myo-inositol trisphosphate isomer generated predominantly by the phytase from Aspergillus niger 11T53A9, kinetic studies with the purified myo-inositol trisphosphate isomers generated either by the phytases from Sacharomyces cerevisiae and the phytase from Aspergillus niger 11T53A9 were performed. The enzymes were added to sequentially diluted solutions of the purified myo-inositol pentakisphosphate isomers and the kinetic parameters $\left(\mathrm{K}_{\mathrm{M}}, \mathrm{k}_{\mathrm{cat}}\right)$ were calculated from the Lineweaver-Burk plots of the data (table 4 ). $\mathrm{K}_{\mathrm{M}}$ and $\mathrm{k}_{\mathrm{cat}}$ for enzymatic hydrolysis of the major myo-inositol pentakisphosphate isomer generated by the Aspergillus niger 11T53A9 and Saccharomyces cerevisiae phytases were almost identical. Since it is known that the Saccharomyces cerevisiae phytase generates the $\mathrm{D}-\operatorname{Ins}(1,2,6) \mathrm{P}_{3}$ isomer (12), D-Ins(1,2,6) $\mathrm{P}_{3}$ and $\mathrm{D}$-Ins $(1,2) \mathrm{P}_{2}$ were the most likely myo-inositol tris- and bisphosphate isomers generated by the action of the phytase from Aspergillus niger 11T53A9 upon phytate.

Table 4. Kinetic constants for enzymatic myo-inositol trisphosphate dephosphorylation

\section{InsP $_{3}$ generated by}

\begin{tabular}{|c|c|c|c|}
\hline phytase & kinetic constant & $\begin{array}{c}\text { Aspergillus niger } \\
\text { phytase }\end{array}$ & S. cerevisiae phytase \\
\hline \multirow[t]{4}{*}{ niger } & $\mathrm{K}_{\mathrm{M}}\left[\mu \mathrm{mol} \mathrm{l}{ }^{-1}\right]$ & $215 \pm 11^{\mathrm{a}}$ & $223 \pm 14^{\mathrm{a}}$ \\
\hline & $\mathrm{k}_{\text {cat }}\left[\mathrm{s}^{-1}\right]$ & $101 \pm 9^{a}$ & $106 \pm 11^{\mathrm{a}}$ \\
\hline & $\mathrm{K}_{\mathrm{M}}\left[\mu \mathrm{mol} \mathrm{l}{ }^{-1}\right]$ & $284 \pm 15^{\mathrm{a}}$ & $293 \pm 12^{\mathrm{a}}$ \\
\hline & $\mathrm{k}_{\text {cat }}\left[\mathrm{s}^{-1}\right]$ & $96 \pm 7^{\mathrm{a}}$ & $99 \pm 9^{a}$ \\
\hline
\end{tabular}

\footnotetext{
Temperature: $37^{\circ} \mathrm{C}$; buffer: $100 \mathrm{mM}$ sodium acetate, $\mathrm{pH} \mathrm{5.0}$; enzyme concentration: $25 \mathrm{mU}^{-1}$. For calculation of $\mathrm{k}_{\mathrm{cat}}$ the following molecular masses were used: Aspergillus niger, $85 \mathrm{kDa}$, Saccharomyces cerevisiae, $60 \mathrm{kDa}(12)$. The data are mean values of five independent experiments. ${ }^{a}$ means within the same line with the same superscripts are not significantly different $(\mathrm{P}<0.05)$
} 


\section{DISCUSSION}

The enzymatic properties of the purified phytase suggest that this enzyme is very similar to the Aspergillus niger phytases reported in the literature $(3,6,18,21,24-27,32,34)$. The subunit molecular mass of the purified phytase was estimated to be $85 \mathrm{kDa}$ by SDS PAGE. This molecular mass is in close agreement with that of the purified phytase (phy A) from A. niger var. ficuum NRRL 3135 (27) and A. niger ATCC 9142 (3). Determination of the molecular mass of the biologically active enzyme was also carried out by gel filtration. A native molecular mass of $85 \mathrm{kDa}$ was reported (figure 1), indicating that the catalytically active form of the enzyme is that of a monomer. This is in accordance with all A. niger phytases reported so far. The enzyme was also found to be glycosylated (data not shown). Glycosylation is a characteristic of many fungal extracellular enzymes, including the phytases from $A$. niger $(3,6,24,27)$.

The $\mathrm{pH}$ versus activity profiles of the purified phytase displayed substantial similarity in having two distinct $\mathrm{pH}$ optima, an identifying characteristic of the phytaseA enzyme from A. niger $(3,25,27)$. As with the phytase from A. niger var. ficcum NRRL 3135, the highest activity was recorded at $\mathrm{pH} 5.0$ and a second activity peak occurs below pH 3.0 (27). Furthermore, the activity ratio of the two enzymes at pH 5.0 and $\mathrm{pH}<3.0$ were very similar. A further characteristic both enzymes have in common is the relatively high stability under acidic condition. Both enzymes retained about $95 \%$ of their activities after incubation for $24 \mathrm{~h}$ at $\mathrm{pH} 2.0$ and $37^{\circ} \mathrm{C}$ (11).

Measurements of phytase activity as a function of temperature revealed only minor differences between the purified phytase and the A. niger phytases reported so far $(3,6$, 18, 21, 24-27, 32, 34). The phytases exhibited maximum activity at about $50-55^{\circ} \mathrm{C}$. As the phytase from A. niger var. ficuum NRRL 3135 the purified enzyme retained about 40-45\% of its initial activity after incubation for $10 \mathrm{~min}$ at $70^{\circ} \mathrm{C}$ (29). It is widely accepted that $A$. niger phytase is not a thermostable enzyme nor does it have the capacity to refold properly after denaturation (33). This is also in agreement with the observation of Gibson (7) who stated that the available industrial phytases which originate from $A$. niger have a low intrinsic resistance to heat inactivation.

Substrate specificity studies (table 2) showed that the purified enzyme accepts phytate as a good substrate. All other compounds tested were only marginally hydrolysed by the purified enzyme. These results are broadly similar to values reported for phytases purified from other A. niger strains (3, 6, $21,24)$. The kinetic constants were also in close agreement to those reported for A. niger var. ficuum NRRL 3135 (25). As the phytase activity from A. niger var ficuum NRRL 3135, the activity of the purified enzyme was unaffected by calcium ions but inhibited by iron (25). In addition fluoride was shown to be a potent inhibitor of the $A$. niger phytases.

A detailed characterisation of the hydrolysis pathway of myo-inositol hexakisphosphate by the phytase from Aspergillus niger 11T53A9 purified to apparent homogeneity revealed that this enzyme dephosphorylates myo-inositol hexakisphosphate via $\mathrm{D}-\operatorname{Ins}(1,2,4,5,6) \mathrm{P}_{5}, \quad \mathrm{D}-\operatorname{Ins}(1,2,5,6) \mathrm{P}_{4}, \quad \mathrm{D}-\operatorname{Ins}(1,2,6) \mathrm{P}_{3}, \quad \mathrm{D}-$ $\operatorname{Ins}(1,2) \mathrm{P}_{2}$ to finally $\operatorname{Ins}(2) \mathrm{P}$. Therefore, this phytase has to be considered a 3-phytase (EC. 3.1.3.26). This is in agreement with the data reported by Ullah and Phillippy (28). In addition, Chen and Li (4) identified D-Ins(1,2,4,5,6) $\mathrm{P}_{5}$, D-Ins(1,2,5,6) $\mathrm{P}_{4}$, D-Ins $(1,2,6) \mathrm{P}_{3}, \quad \mathrm{D}-\operatorname{Ins}(1,2) \mathrm{P}_{2}$ as phytate dephosphorylation products generated by a commercially available phytase derived from A. niger. In addition they found a further degradation pathway proceeding from $\mathrm{D}-\operatorname{Ins}(1,2,5,6) \mathrm{P}_{4}$ via $\mathrm{D}-\operatorname{Ins}(1,5,6) \mathrm{P}_{3}$ to D-Ins $(5,6) \mathrm{P}_{2}$. The latter pathway could not be confirmed with the apparently pure phytase preparation used in this study. The following three reasons point to the correctness of the phytate degradation pathway given here. Firstly, the phytase preparation used by Chen and Li (4) was shown to be contaminated with additional acid phosphatases. It can not be excluded that these acid phosphatases act upon partially phosphorylated myoinositol phosphates generated by the A. niger phytase, even if phytate itself is not a substrate for that enzyme. Secondly, the formation of $\mathrm{D}$-Ins $(1,5,6) \mathrm{P}_{3}$ upon action on phytate would require hydrolysis of the phosphate residue at position $\mathrm{C}-2$ of the myo-inositol ring. This phosphate residue was shown to be 
Greiner, R. et al.

resistant to dephosphorylation by phytases (15). Finally, the phytate degradation pathway is consistent with the preference of histidine acid phytases such as the enzyme from A. niger 11T53A9 to continue dephosphorylation after removal of the first phosphate residue from phytate adjacent to a free hydroxyl group. The only sequence of dephosphorylation which would be in agreement with the results obtained by high performance ion chromatography is C-3, C-4, C-5 and C6.

\section{ACKNOWLEDGEMENT}

Analysis of the individual myo-inositol phosphate derivatives by N.-G. Carlsson, University of Technology (Gothenburg, Sweden) is gratefully acknowledged.

\section{REFERENCES}

1. Bradford, M. (1976). A rapid and sensitive method for the quantitation of microgram quantities of protein utilizing the principle of protein-dye binding. Anal. Biochem. 72, 248-254.

2. Carrington, A.L.; Calcutt, N.A.; Ettlinger, C.B.; Gustafsson, T.; Tomlinson, D.R. (1993). Effects of treatment with myo-inositol or its 1,2,6-trisphosphate (PP56) on nerve conduction in streptozotocindiabetes. Eur. J. Pharmacol. 237, 257-263.

3. Casey, A.; Walsh, G. (2003). Purification and characterization of extracellular phytase from Aspergillus niger ATCC 9142. Biores. Technol. 86, 183-188.

4. Chen, Q.-C.; Li, B.W. (2003). Separation of phytic acid and other related inositol phosphates by high-performance ion chromatography and its applications. J. Chromatogr. A 1018, 41-52.

5. Claxon, A.; Morris, C.; Blake, D.; Siren, M.; Halliwell, B.; Gustafsson, T.; Löfkvist, B.; Bergelin, I. (1990). The anti-inflammatory effects of D-myo-inositol-1.2,6-trisphosphate (PP56) on animal models of inflammation. Agents Actions 29, 68-70.

6. Dvoráková, J.; Volfová, O.; Kopecky, J. (1997). Characterisation of phytase produced by Aspergillus niger. Folia Microbiol. 42, 349-352.

7. Gibson, K. (1995). The pelleting stability of animal feed enzymes. In: Second European Symposium on Feed Enzymes, Noordwijkerhout, The Netherlands, pp. 157-162.

8. Grases, F.; March, J.G.; Prieto, R.M.; Simonet, B.M.; Costa-Bauza, A.; García-Raja, A.; Conte, A. (2000). Urinary phytate in calcium oxalate stones formers and healthy people. Scand. J. Urol. Nephrol. 34, 162164.
9. Greiner, R. (2004). Purification and Properties of a Phytate-degrading Enzyme from Pantoea agglomerans. The Prot. J. 23, 567-576.

10. Greiner, R. (2004). Degradation of myo-inositol hexakisphosphate by a phytate-degrading enzyme from Pantoea agglomerans. The Prot. J. 23, $577-585$.

11. Greiner, R.; Farouk, A. (2007). Purification and characterization of a bacterial phytase whose properties make it exceptionally useful as a feed supplement. The Prot. J. 26, 467-474.

12. Greiner, R.; Larsson Alminger, M.; Carlsson, N.-G. (2001). Stereospecificity of myo-inositol hexakisphosphate dephosphorylation by a phytase of baker's yeast. J. Agric. Food Chem. 49, 2228-2233.

13. Heinonen, J.K.; Lahti, R.J. (1981). A new and convenient colorimetric determination of inorganic orthophosphate and its application to the assay of inorganic pyrophosphatase. Anal. Biochem. 113, 313-317.

14. Jariwalla, R.J.; Sabin, R.; Lawson, S.; Herman, Z.S. (1990). Lowering of serum cholesterol and triglycerides and modulation of divalent cations by dietary phytate. J. Appl. Nutr. 42, 18-28.

15. Konietzny, U.; Greiner, R. (2002). Molecular and catalytic properties of phytate-degrading enzymes (phytases). Int. J. Food Sci. Technol. 37, 791-812.

16. Laemmli, U.K. (1970). Cleavage of structural proteins during the assembly of the head of bacteriophage T4. Nature 227, 680-685.

17. Maffucci, T.; Piccolo, E.; Cumashi, A.; Iezzi, M.; Riley, A.M.; Saiardi, A.; Godage, H.Y.; Rossi, C.; Broggini, M.; Iacobelli, S.; Potter, B.V.L.; Innocenti, P.; Falasca, M. (2005). Inhibition of the phosphatidylinositol 3-Kinase/Akt pathway by inositol pentakisphosphate results in antiangiogenic and antitumor effects. Cancer Res. 65, 8339-8349.

18. Martin, J.A.; Murphy, R.A.; Power, R.F.G. (2006). Purification and physico-chemical characterisation of genetically modified phytases expressed in Aspergillus awamori. Biores. Technol. 93,: 1703-1708.

19. Phillippy, B.Q.; Bland, J.M. (1988). Gradient ion chromatography of inositol phosphates. Anal. Biochem. 175, 162-166.

20. Sandberg, A.-S.; Ahderinne, R. (1986). HPLC method for determination of inositol tri-, tetra-, penta-, and hexaphosphate in food and intestinal contents. J. Food Sci. 51, 547-550.

21. Sariyska, M.V.; Gargova, S.A.; Koleva, L.A.; Angelov, A.I. (2005). Aspergillus niger phytase: Purification and characterization. Biotechnol. Biotechnol. Eq. 19, 98-105.

22. Shears, S.B. (1998). The versatility of inositol phosphates as cellular signals. Biochim. Biophys. Acta 1436, 49-67.

23. Skoglund, E.; Carlsson, N.-G.; Sandberg, A.-S. (1998). High-Performance Chromatographic separation of inositol phosphate isomers on strong anion exchange columns. J. Agric. Food Chem. 46, 1877-1882.

24. Skowroński, T. (1978). Some properties of partially purified from Aspergillus niger. Acta Microbiol. Polonica 27, 41-48.

25. Ullah, A.H.J. (1988). Production, rapid purification and catalytic characterization of extracellular phytase from Aspergillus ficuum. Prep. Biochem. 18, 443-458. 
26. Ullah, A.H.J. (1988). Aspergillus ficuum phytase: Partial primary structure, substrate selectivity, and kinetic characterization. Prep. Biochem. 18, 459471.

27. Ullah, A.H.J.; Gibson, D.M. (1987). Extracellular phytase (E.C. 3.1.3.8) from Aspergillus ficuum NRRL 3135: Purification and characterization. Prep. Biochem. 17, 63-91.

28. Ullah, A.H.J.; Phillippy, B.Q. (1988). Immobilization of Aspergillus ficuum phytase: Product characterization of the bioreactor. Prep. Biochem. 18, 483-489.

29. Ullah, A.H.J.; Sethumadhavan, K. (2003). PhyA gene product of Aspergillus ficuum and Peniophora lycii produces dissimilar phytases. Biochem. Biophys. Res. Commun. 303, 463-468.

30. Vohra, A.; Satyanarayana, T. (2003). Phytases: Microbial sources, production, purification, and potential biotechnological applications. Crit. Rev. Biotechnol. 23, 29-60.

31. Vucenik, I.; Shamsuddin, A.M. (2003). Cancer inhibition by inositol hexaphosphate (IP6) and inositol: From laboratory to clinic. J. Nutr. $133,3778 \mathrm{~S}-3784 \mathrm{~S}$
32. Wyss, M.; Brugger, R.; Kronenberger, A.; Remy, R.; Fimbel, R.; Oesterhelt, G.; Lehmann, M.; van Loon, A.P.G.M. (1999). Biochemical characterization of fungal phytases (myo-inositol hexakisphosphate phosphohydrolase): Catalytic properties. Appl. Environm. Microbiol. 65, 367-373.

33. Wyss, M.; Pasamontes, L.; Remy, R.; Kohler, J.; Kusznir, E.; Gadient, M.; Muller, F.; van Loon, A.P.G.M. (1998). Comparison of the thermostability properties of three acid phosphatases from molds: $A$. fumigatus phytase, A. niger phytase and A. niger $\mathrm{pH} 2.5$ acid phosphatase. Appl. Environ. Microbiol. 64, 4446-4451.

34. Wyss, M.; Pasamontes, L.; Friedlein, A.; Remy, R.; Tessier, M.; Kronenberger, A.; Middendorf, A.; Lehmann, M.; Schnoebelen, L.; Röthlisberger, U.; Kusznir, E.; Wahl, G.; Müller, F.; Lahm, H.-W.; Vogel, K.; van Loon, A.P.G.M. (1999). Biophysical characterization of fungal phytases (myo-inositol hexakisphosphate phosphohydrolase): Molecular size, Glycosylation pattern, and engineering of proteolytic resistance. Appl. Environm. Microbiol. 65, 359-366. 